\title{
Contesting illegitimate situations, reassessing shared norms in contemporary China
}

Isabelle Thireau

\section{OpenEdition}

\section{Journals}

\section{Electronic version}

URL: http://journals.openedition.org/ress/2860

DOI: $10.4000 /$ ress. 2860

ISSN: $1663-4446$

\section{Publisher}

Librairie Droz

\section{Printed version}

Date of publication: 27 November 2014

Number of pages: 133-159

ISBN: 978-2-600-01866-1

ISSN: 0048-8046

\section{Electronic reference}

Isabelle Thireau, "Contesting illegitimate situations, reassessing shared norms in contemporary China », Revue européenne des sciences sociales [Online], 52-2 | 2014, Online since 01 January 2018, connection on 01 May 2019. URL : http://journals.openedition.org/ress/2860 ; DOI : 10.4000/ ress. 2860 


\title{
CONTESTING ILLEGITIMATE SITUATIONS, REASSESSING SHARED NORMS IN CONTEMPORARY CHINA
}

\author{
ISABELLE THIREAU \\ Paris, EHESS - CECMC/CNRS \\ thireau@ehess.fr
}

\begin{abstract}
This paper is based on the analysis of a corpus of letters sent to a specific Chinese institution: the Letters and Visits Administration created in 1951. Its main focus is to analyze the recent trends of this particular space of direct address to State and Party representative. This is indeed a space where situations considered to be unjust, illegitimate, unacceptable are exposed, whether individually or collectively. The article begins by stressing the importance not only of the grievances expressed but of the type of relationship posited by complainants between themselves and those they appeal to, which is also between the ruled and the rulers. It then considers how letters and visits enable those who take such initiatives to step outside the private realm and tell public authorities who they are and, more precisely, how they perceive themselves. Finally, I will try to explain why the shared arguments put forward by petitioners, although they often rely on official commitments, cannot be understood as expressing a mere inclination towards rule compliance.
\end{abstract}

Keywords: China, legitimacy, Letters and Visits Administration, norms, sense of justice.

Résumé. Ce texte prend appui sur un corpus de lettres adressées à une institution chinoise particulière: l'administration des Lettres et des Visites créée en 195I. II a pour principal objectif d'analyser les développements récents de cet espace d'adresse directe auprès des représentants du Parti et de l'État. II s'agit en effet pour ceux qui investissent cet espace de parole, que ce soit à titre individuel ou collectif, de révéler des situations jugées injustes, illégitimes, inacceptables. L'article commence par souligner l'importance non seulement des griefs exprimés mais de la relation que les plaignants rendent manifeste dans leurs lettres entre eux et ceux auxquels ils s'adressent, soit entre gouvernés et gouvernants. II analyse ensuite comment lettres et visites permettent à ceux qui prennent de telles initiatives de sortir du domaine privé pour dire aux autorités publiques qui ils sont et, de façon plus précise, comment ils se perçoivent. Enfin, une dernière partie s'attache à expliquer pourquoi les références partagées mises en avant par les pétitionnaires, même si elles s'appuient souvent sur des engagements publics, ne peuvent être interprétées comme manifestant simplement la disposition à agir de façon conforme à la règle.

Mots-clés: administration des Lettres et des Visites, Chine, légitimité, normes, sens du juste. 
During the months following the creation of the People's Republic of China, in October 1949, the senior officials of the Communist Party were described as being accessible to the public and eager to personally respond to their letters. On I6 May I95 I, Mao drafted a message in which he encouraged the creation of offices that would specialize in responding to the people's letters and visits (Diao, 1996, p.3 I). Such offices-intermediary bodies between the population and existing political or administrative services - were gradually set up starting from the capital, through provincial and municipal levels to finally reach local authorities at district level and, nowadays, township level (Thireau and Hua, 20ıо; Minzner, 2006).

The accounts, which quickly poured in, were divided into four main categories: "accusing and denouncing" unlawful actions or actions violating the Party's order; "appealing" against an administrative, political or legal decision; "expressing criticism or suggestions" in order to improve the work of the administrative services, social conduct or productivity; "seeking assistance" when one's (or one's family's) vital interests are threatened'.

Since the start of the 1980s, this Letters and Visits Administration has been dealing with a steadily increasing number of cases. Such increase reached an average of $10 \%$ between 1992 and 2004. During 2004, the main offices, those dealing with general appeals without specializing in a particular field (such as education, labour or the environment), received i 3736000 cases (see Zhengming, 2004, p.I4). The year 2005 marked the start of an official decline in the number of cases, although no further statistics have since been made public (see Renmin xinfang, 2006, p.I5).

This paper is based on a corpus of seven hundred letters gathered randomly, sent between 195 I and 2012 to Letters and Visits Offices located in different regions and municipalities, as well as interviews with petitioners and those who deal with them. It addresses some of the recent trends observed as far as the writing and content of these letters are concerned. Although the aims pursued by those who turn to the Letters and Visits Administration inasmuch as their grievances are

I See for instance Xinfang, jubao, shensu bibei [Necessary documents for letters and visits, reports and appeals], 1990, p.21. 
varied, recurrent patterns through which given practices and situations come to be designated as illegitimate, unjust, or unacceptable, can indeed be identified.

In order to better grasp these letters' characteristics, I will engage in a brief comparison with another space where situations faced by members of Chinese society were once described as illegitimate. As a matter of fact, one of the main laws promulgated by the new People's Republic, on June 30, 1950, was Land Reform (although the agrarian reform occurred from 1947 to 1952 due to regional variations). The "Speak Bitterness meetings" during which public speech about one's past hardships was encouraged were, much more than land redistribution itself, the defining moments of Land reform. The comparison between these two different situations and ways to confront "what is" to "what should be", is meant here as a heuristic device to better point out what characterizes the actions of those who nowadays resort to this specific procedure of direct address: writing or paying visits to the Letters and Visits Administration.

\section{I.DISCLOSING THE EXPECTED RELATION BETWEEN RULERS AND RULED}

Deng Xiaoping's political and economic reforms of the late I970s signalled the end of the class struggle principle: the class label system disappeared and the prevailing ideology explaining both past and future was given up. As a result, the scope of members of society likely to provide oral or written accounts and the range of situations likely to be contested widened. Moreover, the exclusive language that was once dominant has ceased to be, hence forcing the authors of letters and visits to think, inquire, select and combine the most relevant ways to describe and interpret their situation.

As a consequence of the new diversity of situations depicted, yet another classification was added in order to draw basic distinctions between the letters received. From then on, there were to be the "problems inherited from the past” (i.e. accounts concerning events, often political campaigns, which occurred prior to the reform era) and the "current problems" originating in the multiplicity of new situations and tensions arising from reform. The content 
of letters - or emails — and visits continued to evolve on an almost yearly basis, e.g. requests of political rehabilitation, issues regarding hukou or household registration certificate, employment problems, working conditions, local election fraud, etc. However, six issues have been dominant since 2000: agricultural land expropriations; urban demolitions and resulting expropriations or forced movements; the effective functioning of legal institutions; labour law; environmental concerns; safety questions (see Qianfeng, 2006, p.II).

The weight of such grievances can be illustrated by the texts of 142 laws and directives found in Beijing, on October 2I, 2005, in the makeshift stand of a petitioner. Coming from the Heilongjiang province, he was selling documents that might support the complaints put forward by those who travel to the capital after having exhausted attempts at petitioning their local Letters and Visits Offices. These documents dealt with expropriations and property demolitions (5), administrative law (9), farmland ownership regulations (I0), criminal law (II), labour law (22), compensation procedures (28), civil law (36) and various documents about the Supreme Court, the Public Prosecutor's Office, Public Security, the Police and the Army (2I). No distinction was made between laws and directives as they are all considered as having the force of law. There were also 73 recent newspaper clippings, sorted into appropriate categories, citing public declarations by Chinese leaders regarding the issues mentioned above. Finally, as well as songbooks, one could find the text of the recently promulgated national regulation defining the rights and obligations of the personnel of the Letters and Visits Offices as well as those referring to it. A few years later, on April 25, 2012, in Beijing again, a complainant from Sichuan was selling files whose content was much similar, although increased attention was now given to compensation procedures in case of a health problem caused by a third party (adulterated food, toxic drugs, misdiagnosis, negligent care, etc.).

Another recent development is that using the Letters and Visits system is perceived as only one of several possible avenues of action which can be complemented by other initiatives: taking a legal action; becoming involved in a collective action such as strikes, work stoppages or occupying local authority offices; approaching the press or posting details of wrongdoings suffered onto the Internet. 
The letters sent to this administration are varied and seem to preclude any attempt of generalization, as shown in the examples below. In the first case, the letter was written by a private entrepreneur in a famous case of expropriation of oil wells, while the second one has been written in August 2007 by a Beijing resident complaining about the privatization process of a public pathway:

Dear and respected President Hu Jintao,

My name is Wang An. It has now been two years since I have become some sort of fugitive forced into hiding from both the authorities in the city of Yulin who want to arrest me, and from the hoards of those who have lent me money and who can no longer contain their anger. I do not know how much longer I will remain on the run, nor do I know how this will end. Originally I was a lowly farmer who kept to his place and who chose to spend all his energy taking the risk of trying to exploit the oil wells in Yulin in the north of Shaanxi province. I had signed a contract with the local authorities and then suddenly, two years ago, the police, the public prosecutor's department and the courts rallied together and came armed to seize my oil wells. [...] President Hu, I do not have enormous experience of the world, but I know what rules should be respected. A government which forcibly takes possession of the property of the people, whatever the dynasty or era, is clearly wrong. We have committed no crime, no matter how small, but nevertheless, the local authorities want to arrest me to prevent me from lodging a complaint. They are ready to do anything to find me and at one time there were several hundred people looking for me. At the present time, many like me have suffered terribly for wanting to complain against the Yulin government. I cannot continue to live in this situation. I am Chinese and you are the President of the Chinese. What would you have done in my place? I hope that you can help me! (Gao, 2006, p.39)

Dear respected Mayor,

I hope you are well. My son Ma Wei wrote to you at the beginning of June to bring to your attention and to challenge the fact that the Overseas Chinese Residence has started to consider as its own a passageway that has always been a public right of way. They have installed barriers and have imposed the necessity of buying a ticket onto those who wish to use it, thereby preventing the locals from moving around as they have always been able to. Today, two officials from the resident committee $\mathrm{X}$ came to see my son to give him a document that the Residence had written in response to questions asked by the local legal services about this case. In reading this document, I had some thoughts that I wish to submit to you in this letter. [...] 
2) The document states that "there would be security problems if idle individuals with no clear position were allowed to wander freely through the passageway". This claim cannot constitute a justification for the closure of this passageway or for the introduction of a ticket system.

a) The so-called "idle individuals with no clear position" are also citizens of our country. They have the right to come and go as they wish. As far as I know, there are no national directives forbidding "idle individuals with no clear position" from using public passageways in certain residences, areas or towns. Preventing these "idle individuals with no clear position" as well as other locals from using a public passage is therefore against the law. If the State spends money maintaining public rights of way, it is indeed so that people may use them. People are not discriminated against whether they are from North or South or young or old. Everyone has the right to walk around the town. In acting as it has, the Residence is violating people's right of movement-which is a fundamental human right-and acting in a way that is contrary to reason (Peking, 2007, letter I5).

The corpus of letters written during the last two decades, from which these two examples originate, reflect the diversity but also the intensity of the grievances expressed. Moreover, their authors, who come from the main strands of Chinese society — such as farmers, workers, migrants, landlords, teachers or public service users-mostly complain about the local Party and State representatives. In $86 \%$ of the 450 letters collected written between I99 and 20 I, the authorities of the village, canton, district or town are being complained against - the remaining $\mathrm{I} 4 \%$ being managers of public services (hospitals, airports, motorways) as well as company bosses.

However, this corpus also discloses that one of the main changes regarding the grievances expressed does not lie in their growing intensity, in their increasingly collective dimension or in the nature of the wrongdoings described, but in the crucial importance assigned by those who take the floor to the interaction process between themselves and those they address. It is not here a matter of just saying that the context of enunciation-who speaks to whom? in front of whom?- - has an effect on the way situations are exposed rather than saying that these letters are an appeal to public authorities inasmuch as they disclose the wrongs endured. As a matter of fact, $94 \%$ of the letters cove- 
ring the years i99 I to 20 I are addressed to State and Party leaders at various levels rather than to the personnel of the Letters and Visits Offices. In addition, State and Party authorities are increasingly called upon not to act as judges or arbitrators in disputes between two parties but as individuals responsible for what one of the parties, technically placed under their authority, is inflicting on the other. The willingness to engage in a kind of face-to-face dialogue with higher Party and State representatives is also evidenced by the fact that during these years of continually increasing figures, visits increased at a greater rate than letters, collective cases increased faster than individual cases and those addressed to the central offices increased faster than those addressed to the local offices (Yu, 2005, p.212-219).

More importantly, the dominant relationship which permeates these letters and organizes the way they are written is that established by the petitioners between themselves and their addressees, and not that existing between the petitioners and those hold directly responsible for the injustice experienced. Complainants stress that they are appealing to those in charge and that, as a consequence, those they address are the rulers and they themselves are the ruled. In other words, the presumed relationship between rulers and ruled, that overlaps the relationship between these letters' authors and their readers, guides the way the situations put forward are selected and described from a factual as well as normative point of view. A relationship between "I" (or "we”) and "you" is developed by those who speak out. They raise questions, confront the rulers to existing divergent interpretations of a given situation or action and ask them to choose among them. They do so in a situation where they are the ones who took the initiative to speak, whether in an oral or written form, and thus provide an initial description of the expected relationship that cannot be controlled, or contested, beforehand. In other words, this space is often used today by those who step into it as what it pretends to be: an interaction space between the government and the governed. As such, it is a space where specific forms of dialogue and interjection are deemed legitimate and expected. 
In these statements, the description provided of the relationship existing between the two parties leads to a specific positioning of oneself and the other anchored in a definition of each party's obligations towards each other. As Wang An says in the above letter: "I am Chinese and you are the President of the Chinese". Such positioning is grounded in a certain number of political and moral assumptions presumed to be shared and which contribute in return to validate or invalidate each side's position. Both the relationship and the positions described are not merely factual; they rely on specific interpretations of what should be versus what should not be. In other words, they encompass duties and responsibilities. They are described in terms of legitimacy, the petitioners for instance highlighting not only the illegitimacy of the wrongdoings inflicted on them, but also the illegitimacy of the authorities' lack of action when faced with abuse carried out by those they should be able to control.

The specific manners used by complainants to address State and Party leaders thus encompass political expectations presumed to be shared. These expectations are expressed precisely through the claimants' actions and words. It is worth mentioning here the work of Hannah Arendt (1958, p.I83-I84), who understood power as a relation rather than something that can be acquired, and action as mainly the start of something new in human relations. In this sense, one can argue that appealing to the State and Party representatives as a relational move constitutes in itself an political initiative that cannot be disconnected from power relationships. However, the argumentation process observed in these letters also echoes Anne Cheng when she says: "The continuities between the parties and the whole is also encompassed in the Chinese thoughts about the relationship. This one is not understood as a simple link being established between pre-existing entities, but it is contitutive of the beings in their existence and their future." (1997, p 4I). One could borrow such formula and say that a relationship $\mathrm{R}$ embodied by the fact that $\mathrm{a}$ is appealing to $b$ generates both terms of the relationship: the one who appeals-in this specific case the ruled - and the one who is being appealed to - the ruler. 
One thing is certain: the expected, presumed relation between rulers and ruled as it is disclosed by petitioners in their letters reveal how they perceive and envision their power over each other. Therefore, not only should we analyse the content of grievances and the complainants' social indicators which can explain their actions (although in a somewhat mechanical way), but we should also look into how the argumentation used and the relationship implied therein effectively assigns the authors of petitions and their addressees a specific position, and thus specific duties and expectations.

Without going into the detail of the various components of the relationship thus assessed between the government and the governed, let us point out some of the recurrent expectations found in letters. Although they do not form a consistent political theory, they do represent fundamental political expectations as shown for instance in the argumentation process developed in the two letters mentioned earlier:

I wish to make some remarks concerning the residents committee of $\mathrm{N}$.

The quality of the work carried out by this committee is extremely poor. The local authorities that we have contacted asked this residents committee to resolve the problem brought about by the privatization of a public passageway initiated by the Overseas Chinese Residence, thereby obliging those wishing to use it to buy a pass. They took no action but came into our building to find my son - who wrote the first letter of complaint on this subject - to give him the first written response that the Overseas Chinese Residence made to the legal services in our urban district. I found this somewhat unusual. In stating that their work is poor, I mean that they know nothing about basic procedures that must be followed in order to deal with this kind of situation. All they did was deliver the mail and, even worse, they delivered the wrong letter to the wrong person. They should not have given us their response to the questions asked by the legal services following our complaints, but the formal reply that they, as the residents committee, made to the Residence's claim. This formal response should have been made in two stages. Firstly, after being commissioned by the local authorities to resolve the matter, the committee members should have studied the documents handed in by various individuals, gone to meet the different parties and called meetings about the issue. Then, they should have compiled a response explaining the reasons for their agreement if they accepted the privatization of this public passageway and their reasons for their disagreement if they disapproved in setting a deadline for the reopening 
of the passageway. We have received no such letter from the local authorities to whom the case had been officially referred. This is why I deem the work carried out to be poor (Peking, 2007, letter I5).

Rulers, for instance, have a duty to listen to those they lead, and especially to their desire for justice. Some letters, in the manner of the one quoted above, even suggest a description of what listening means today.

Human beings are born of their parents and are brought up by their parents. President $\mathrm{Hu}$, how would you react if all the members of your family were separated? What would you do if your wife had to leave you? What solution would you find to pay back such a large debt? We need you to take action and re-establish justice (Gao, 2006, p.39).

Rulers also have a duty to be answerable to the governed. Such expectation is often expressed by authors of letters by mentioning that, if those they turn to cannot grant their request, they should at least provide a response (说法). Besides, as shown in the above letter, the relationship by which all parties are bound is based on an increasing demand to equalize positions. Complainants expect leaders to use their imagination and be capable of exchanging their positions with those they govern to gain a better understanding of their situation, a demand recognising the equal humanity of both sides. Not only are leaders expected to think by putting oneself in other peoples' position, the ultimate way of political thinking according to Arendt (2005 [2003]; Revault d'Allones, I99I) but they are given hints as to how this should be done.

Surely there must be a branch of the Party present in this Residence. I think that they should carry out a study from three perspectives. Firstly, those who made these decisions and who run the Residence must study the directives and the existing laws as well as property management books and the Party regulations. Secondly, they must walk around the neighbourhood, observe how such problems are resolved there, overcome their fears and get a sense of reality. Finally, they need to go to the National Library and read historical novels and autobiographies to find out about links that existed in past times between neighbours. They should write out these descriptions and stories and keep them to heart [...]. I consider that I have the right to write you this letter. I am a citizen of our Republic and a member of the Party. According to the Constitution and the Party regulations, I have the right to level criticism at 
higher authorities. I think that my status also permits me to write to you. I was a representative of the local residents until the area was reorganized [居民代表]. So many times have I been called upon by the residents committee to help carry out certain tasks! So many times have I discussed the Residence's situation with other representatives! The local residents are outraged. Some of them say: "The present government is the government of the rich and will not speak for the poor." [...] I cannot present here all the viewpoints that have been expressed, but I can say that if some claims are too radical and others are very much to the point, they all have one thing in common: they reflect the outrage and anger of the local residents (Peking, 2007, letter I5).

Furthermore, the relationship established between leaders and citizens is based on the right of the former to tell the latter how they should act in given circumstances, such assumptions acting as a reminder of what supports the latter's political legitimacy.

Not being subjected to arbitrary power, especially from local authorities; being treated by others, including those who hold economic or political power, with humanity and equality; having the right to participate in public affairs, which above all implies having the right to state facts as they are: such are, it seems, some of the political claims which have increasingly prevailed in the collected letters since the beginning of the 2000s.

It should be added that the relationship between the various parties is often described by assessing what rulers should not do or allow to be done to those ruled, rather than stating what they should do. In other words, the focus is put on defining the field of illegitimate actions carried out, on a political or moral level, by the public authorities towards the governed. Pointing out unjust types of relationships, identifying what is off-limits and defining inappropriate action modes are indeed the processes most commonly used in the letters or during visits to delineate the expected relationships. The description of certain forms of relationships as unacceptable thus brings to light the shared and relevant political or moral principles that have been transgressed. This explains the frequent use, after a description of an event that should not happen, of questions such as "Is this acceptable? Is this attitude at all reasonable? Is it fair to be treated this way?" Not only do these questions reaffirm a dialogical relationship but they 
also call for either a negative answer corroborating the complaints and their underlying normative interpretation, or a positive answer which then reveals that it is the rulers who have distanced themselves from common principles.

It should be highlighted that the specific grammar of action mentioned above, which legitimizes the movement from a relationship towards its various terms, was widely used and somehow perverted by the Chinese Communist Party in order to take power and keep it through "mass mobilization", i.e. confrontations provoked among the people or between the people and its enemies-according to the language of the time. We cannot do more here than allude to the first example of such mass mobilization constituted by the "Speak bitterness meetings" that were organised during land reform. Although these meetings occurred at different moments and with local variations around the country, they share basic common features². Let us state some of them very briefly. Such meetings were hold after the arrival of land reform teams and were sometimes supported by ad-hoc committees such as "speak bitterness committees". In each village, the land reform team gave the floor to specific village members, identified and trained to recall their past sufferings using the largely unfamiliar vocabulary of the new ideology. If some teams initially allowed any local inhabitant to speak out, restrictions were quickly imposed regarding the identity of those who could take the floor, the type of events that could be narrated and the words that were to be used to assign them a new meaning and interpretation. The training process was brief and open only to those selected. In order to test the speakers' ability to make moving accounts of past sufferings embedded in the new ideology, small group "speak bitterness sessions" usually preceded public sessions (actually semi-public sessions since politically suspected villagers were not informed and thus would not attend the meetings) $)^{3}$. More importantly, land reform teams requested villagers to shift from abstract and general accounts to the exposure of specific village members accused of having wronged, abused, mistreated or abuse them. During the

2 On Land Reform in China, see for instance, amidst an important literature: Hinton, 1966; Huang, 1995; Gao and Liu, 2007.

3 Wu Shenlei, interview, New York, July 8, 1999. 
meetings, these accused members received insults and might be beaten; others would be executed afterwards. If part of the vocabulary used was new and linked to class-struggle ideology, the formal objective of "speak bitterness meetings" was not to identify local classes or groups. It was rather to incriminate concrete individuals by claiming that they embodied these classes and that, as such, they could be attacked and lose their local status and position. Moreover, formal class labels were not assigned to local inhabitants during this first sequence of land reform but at the beginning of the second sequence: land redistribution. As a consequence, in many villages, part of those who were accused during the "speak bitterness meetings" or suspected and thus prohibited to participate to the meetings would later on formally be recognised as good class elements. In other words, the distribution of the village population into classes was less on the agenda than the accusation and ostracism of those who previously hold some prestige and were listened to, or feared, in the village.

Training was supported by handbooks gathering speak bitterness accounts deemed exemplary and thus featuring dramatic situations such as farmers confronted to local landlords' cruelty and pushed into beggary or forced to sell their children ${ }^{4}$. But as "speak bitterness" accounts had to be made in each village, their content was very diverse and bore sometimes little resemblance with the extreme situations depicted in the handbooks. Moreover, accounts were provided in highly different contexts ranging from, on the one hand, villagers willing to take the floor for reasons themselves varied to, on the other hand, villagers forced to speak in order to protect themselves from political retaliation and who would sometimes come and visit in the middle of the night those they had accused to ask for their forgiveness 5 . Some villagers would strongly decline, despite the team pressure, to incriminate given people or situations while agreeing to expose others ${ }^{6}$. If the language used was a combination of new ideological concepts and former expressions, the fact that the new poli-

4 See for instance the handbook called Suku Fuchou. Suku dianxin cailiao (1948).

5 Mai Leiguan, interview, Ping'an (Guangdong), April 5, 2007; Wu Meisen, interview, New York, March 13, 200I; Mai Jishen, interview, Ping'an (Guangondg), June 8, 1999.

6 Wu Luanqi, interview, Hong Kong, March $3^{\text {rd }}, 1998$. 
tical terms and slogans were publicly used to make sense of past experiences, the emotions sparked, especially tears, seemed in return to confirm the legitimacy of the new ideology. In other words, the often asked questions "Were peasants willing to take the floor? Could they speak the truth using this new unfamiliar vocabulary?" are not really decisive. Speak bitterness meeting were above all political devices set up in each village in order to arouse face-to-face confrontations, divide communities, legitimate political terror, and set up new power organs. Each sequence, although resulting officially from "mass mobilization”, was actually carried out under the pressure of CCP representatives.

"Speak bitterness meetings" were thus face-to-face confrontations during which given individuals were encouraged to publicly express an accusatory relationship, generating the negative positioning of the other and one's own positive positioning in the newly-established social hierarchy (Thireau and Hua, 20I2). The accused was guilty by the mere fact of being accused: he could not challenge the accusation made against him or herself and the resulting social position assigned to him or her.

If Letters and Visits bureaus were officially meant at the beginning to allow the State and the Party to keep in contact with the population, to be informed about the state of society, to facilitate the supervision of local administration but also to bring support to class struggle (Guo, 1992); if they were initially bound to receive accusatory accounts against class enemies much similar to those expressed during the "speak bitterness meetings", they were rapidly overwhelmed by denunciations regarding local cadres before becoming, in the recent years, one of the main spaces of appeal to political and administrative leaders. In other words, the expected dominant relationship, that between the accuser and the accused, shifted to that between rulers and ruled. 


\section{SAYING WHO YOU ARE BY REJECTING WHAT IS BEING DONE TO YOU}

"Speak bitterness meetings" aimed primarily at positioning particular local inhabitants as bad elements. In letters and visits, the relational movement unfold reveals complainants' interpretation of the positions occupied by of both sides. It allows them to assign rulers a given position (and thus specific duties and obligations) but it allows them also to define how they consider themselves. As a matter of fact, one of the reasons why these appeals matter - whether the response from the services is effective or not, immediate or differed, direct or indirect-is that they enable complainants to step out from their private world and tell others, and more pointedly public authorities, how they envision themselves.

"I live in X Village in the canton of Y. My name is Li Haiwu, male, 35 years old (Shanxi, 1992, letter 34) ": for someone who turns to the Letters and Visits Administration, an obvious way of positioning oneself is to give one's name or to answer the question "who is speaking?” by giving one's basic details.

I, Zhang Beiyong, 66 years old, joined the Party in 1944 and one year later I joined the army and fought for five years until Liberation. Then, I fought three years more in Korea. I was then appointed to the transport office in district $\mathrm{X}$ in Shanxi where I worked for 37 years. I acquired several merits during those years and received in total 17 awards for my work. I am originally from Hebei in $\mathrm{X}$ Village in the canton of $\mathrm{Y}$ in $\mathrm{Z}$ district. This is my life story: between the ages of 18 and 20 I was a member of the Communist guerrilla army and at 20 I volunteered for the army (Shanxi, 1992, letter 41).

As shown in this example, some introduce themselves with a few elements of their life stories. There are letters which even start with several pages of autobiographical details before facts are actually tackled.

However, those turning to the Letters and Visits bureaus tend more and more to reveal their unique individuality, their awareness of being that individual human being and not another one, by establishing the accounts made as their own in using the pronoun "I". For example, the study of 450 of the letters from 1991 to 20I - -written by farmers, city dwellers as well as migrant workers from various regions (Beijing, Shenzhen, Canton and the Shanxi and 
Shaanxi provinces) - reveals that the pronoun "I" is used I times on average in each account, with 2 to 44 occurrences. Whereas in the I950s "I" was often superseded by a category or a collective entity, it is now used to assert oneself as the author of the written words. "I ask the Party and the people to pass fair judgement upon me”, wrote on i November 1986 a former rightist asking for his name to be cleared. Another example:

I looked at the legal information website of the government of Shaanxi province. I saw no law document available for viewing. In the top left corner it states that in order to consult these documents, it is necessary to become a member of the site by calling the following number: 029-87292466. I called this number and was told that membership costs 300 yuan per year. Laws and national or provincial directives are resources that belong to everyone, they are a way for our government to make public the rules that must be obeyed. This official site should be for sharing resources, not making money. I advise therefore the government of our province to complete the site and to make the documents it contains freely available to the public (Shanxi, 1992, letter I).

This "I", which shows that one thinks for oneself, and dares to be oneself, also reveals a "we" which almost never appeared during the first three decades of the regime (except in letters written by cadres of the Party to the leaders, assuming they could claim common membership or judgement). A large number of letters are now collective-several people sharing a common experience, state or feeling and speaking out. In a corpus of letters from migrant workers in Shenzhen, 91 out of I23 letters deal with the living or working conditions faced by several of them. In 7I cases, the author of the letter becomes collective, whether by naming representatives (with those involved signing at the end of the letter), a group (the factory members, the workshop members) or using a more vague signature ("dozens of workers from the factory of X"). The term "women" (we, us, our) is recurrent: 27 times on average in the 7r accounts (between 18 and 43 times in each letter). It is used to express either the possessive (our survival, our request, our law, our situation, our interests, our work), or by the collective subject introducing themselves ("twenty of us have been trying to visit various city council services"), or taking action ("we have pressed charges against our manager who has been abusing our working rights"), or suffering 
("we have been forced to work until 3 or 4 am"), but also demanding ("we wish to be informed of rates paid for piecework and all wages"), or finally to express hopes ("we hope an investigation will be carried out") (Shenzhen, I007, letters 2I et 20). But sometimes, "I" and "we" can be incorporated into a larger, more abstract group ("the community of those who have come to Shenzhen to work") (Shenzhen, 1997, letter I21) or linked with others who, even though remote and anonymous, face similar situations ("what I am describing here also happens in many factories in Shenzhen”) (Shenzhen, 1997, letter II8).

Moreover, those who speak in the first person pass judgements that testify to their own abilities and knowledge. "I wish", "I think", "I say”, "I consider"- -authors of accounts frequently use performative verbs, provide an interpretation of the situation and appraise other people's actions, constantly comparing what was done to what should have been done.

However, authors of accounts also reveal who they are by bringing out how they perceive themselves, that is how they relate to themselves. More precisely, they often introduce themselves as persons who wish to be treated as human beings, citing the general principles that should ground relationships between individuals. Among these principles comes the principle of equality, which is not mentioned in an abstract and general way but through the description of specific practices that violate it. This principle therefore appears by default: it is revealed by deceived expectations which themselves are brought into light by descriptions of the unacceptable situations inflicted upon the complainant. The complainants will state that they perceive themselves-and want to be perceived-as persons who do not accept the situation inflicted upon them, even if they cannot remedy to them. More precisely, they do not want to be seen as persons unable to react, or even worse, agreeing with the situations experienced. Through a variety of words and expressions, they thus express the refusal of being humiliated by actions leaving the victims no other choice but to be passive. "To sum up, we are too persecuted, our suffering is difficult to describe, we earn very little money per day and then we must pay all these fees to these parasites who insult us and even beat us up. We cannot take it any longer"; "We are badly treated, we cannot go on bowing our heads"; "It 
is unfair! We are going through hell. How can we sit here and do nothing?" (Shanxi, 1996, letter 9; Shenzhen, 1997, letters 37 et 38).

In other words, letters often articulate descriptions of how complainants position themselves with the localization process of the principles transgressed by the situations they are confronted with. They disclose that a line has been crossed: the threshold of ill-treatment that a human being can suffer without taking action has been surpassed. They show that such offences are a negation of the victim's right of action and that doing nothing would destroy their selfesteem. Other people's behaviour cannot be left without a response at the risk of depriving those who are subject to such behaviour of the qualities that make them worth of respect to themselves as well as others. Whereas we have been using the term "human being" in the singular, authors of accounts often switch from "I" to "we" in the same sentence- they do not refer to an abstract being but to a plurality of beings living amongst other beings and their reciprocal relationships. A son whose mother makes a living for both of them by scavenging the dustbins of a university and was hit by the security guards; a formerly rich farmer from Hunan province, under the constant abuse of the local Party secretary in spite of the end of class status, whose house was destroyed and whose son was imprisoned; farmers expropriated from their land and deprived of income; female migrant workers who say they can no longer take working conditions that threaten their health; well-off landlords who have been authoritatively informed of so-called non-profit public development projects outside their properties: such are the extremely diverse situations which lead to their speaking out, partly or primarily motivated by the need to affirm — as Vincent Descombes (20I0) puts it—what you are, rather than who you are.

Situations calling for such responses are thus diverse and they vary in time; they can be tragic or not. Nevertheless, it is difficult to understand the long-term actions taken sometimes (writing repeatedly to the administration services, calling in, organizing arduous and costly journeys to the capital, or staying there for several months or even years), if one ignores that those who petition the authorities mostly try to position themselves, in their own eyes as well as to others, as persons recusing the situations inflicted upon them. 
As we have previously seen, actions regarded as humiliating are challenged in the name of the general principles which are seen as the basis for relationships between individuals, and thus between the government and the governed. One of the principles is to protect, or at least not to harm, human life and to ensure its continued well-being. Threats posed to the lives of complainants are sometimes to be taken literally. "We no longer have the means to keep on living"; "How can we survive in such conditions?"; "Please come and see for yourself how little respect some people have for the lives of their employees"; "We no longer look like human beings"; "What is left for us to do but wait for death?". Such statements coming from migrant workers at the end of the I99os are associated with descriptions of bad living and working conditions threatening their health and survival (Shenzhen, 1997, letters 20, 31, 70 and 74). But the spectrum of offences denounced in the name of such a vitalist perspective has significantly widened nowadays, from threats to the physical lives of individuals to disregard for the living conditions necessary for their well-being. Expensive healthcare, misbehaviour by certain doctors and pollution caused by companies or development projects are examples of threats to human life attributable to other individuals. From migrant workers claiming that they are so ill they no longer look like human beings, to the letter below showing the frustration of a Beijing resident faced with constant roadwork threatening the safety of pedestrians, a whole range of complaints can now be expressed in the name of this principle, summoned by people from very different social backgrounds.

Respected Mayor,

I hope that you take the time to read my letter, which comes from an ordinary resident of the capital. Today I would like to tell you about the life-threatening dangers that people face when taking Avenue X in Y locality in Z district. It is the only avenue that ten thousand or so inhabitants of Residence number 5 can take to go into town, and as there are roadworks in the neighbouring streets, much of the other traffic has been diverted this way. This avenue has been worked on since February 2007. In March, the pavements were removed to allow the necessary work to take place and some twenty or so traffic lights that allowed pedestrians to cross were taken away. [...] It is now November and nothing has changed. As a result, cars narrowly avoid pedestrians, the thousands of people who come and go from Residence number 5 feel constantly at risk, and when it 
rains, as nothing has been cleaned and there are potholes everywhere, it is easy to slip and fall. These thousands of people are therefore faced with danger on a daily basis. The situation is extremely unsafe. I hope that the local authorities will be able to coordinate the relevant services, increase their efficiency and quickly resolve the problems I have just described. The work needs to resume as soon as possible, so that the residents can come and go safely (Peking, 2007, letter 5).

Actions threatening human life and denying the principle of equality also infringe an individual's right to make their own life choices-hence their scope for action. Those who speak out also ask for the necessary means to draw up projects and carry them out, and thus to contest other people's arbitrary and illegitimate actions that deprive them of a form of self-fulfilment.

Authors of letters sometimes describe their own position by acknowledging the responsibility they assign to themselves towards other people, close to them or not. A large number of the letters officially filed as "Criticisms and suggestions" (or other categories) thus actually address issues of identity, judgement and responsibility. For example, a Chinese protestant vicar in his forties explains:

My father and I have written over five hundred letters to the Letters and Visits Offices. We wrote to different levels, we wrote to Wen Jiabao several times. It is a matter of responsibility. Too many things are unacceptable to us and we cannot get used to them. For example, we have often written about the hukou (residence permit) system which has introduced so much inequality. Every time, we hope that our letters will be of some use, but we write mainly because we cannot just sit here and do nothing. If we did, we could no longer look ourselves in the face (Gu Kuanlai, interview, Peking, April 21, 2012).

\section{A Tianjin resident recounts:}

I am constantly writing as there are just so many things that I cannot put up with, day after day. Saying nothing would mean I have washed my hands of a situation or that I consider myself to be completely powerless. So, I write. I write mostly to the Letters and Visits offices of the People's Daily and the New China News Agency, hoping to find the words and arguments which would allow my letter to be filed in the Internal References (内部参考) rather than be forwarded to the lower levels. This is my objective, because I know that the leaders will then read it" (Du Senlin, interview, Tianjin, May $3^{\text {rd }}, 2012$ ). 


\section{STATING SHARED ARGUMENTS WHICH COMPEL OTHERS}

In this letter, we would like to address some issues and we hope that you will have the time to read it. We belong to the community of those who have come to work in Shenzhen temporarily. We had some idea of what to expect and what businesses we would find here. [...] We support the policy of economic reform, we are part of it, but there are two sides to every coin and there are some facts that we cannot ignore. [...] We are fully entitled to speak up for our interests and the Government and Party must have confidence in the people. We would like above all to address two issues: the working hours are too long and the pay is too low. [...] The Labour Law gives us inalienable rights that nobody can violate and yet, although we are working on Chinese soil, we feel that the State does not care about us. What difference is there between the French and British concessions that existed before 1949 in Shanghai and our current situation? The Chinese bosses serve the foreign bosses. They are their lapdogs and consider us to be their slaves. They protect the capitalists and harm our interests, exploiting us and reaping the profits of our work in exchange for various advantages. [...] We do not trust the Labour Office, strikes are useless, so it is quite logical that we voice the need for a new revolution and that we fly the flag embroidered with the words "Workers of the world, unite!" Please accept our apologies if some of our words have offended you!” (Shenzhen, I997, letter I2I).

While most authors, in a more or less explicit manner, assert the specific relationship existing between themselves and those they write to; while most of them identify themselves as people capable of judgement, all of them describe unacceptable facts as well as point out the norms or principles that such facts transgress. If it is not this paper's aim to mention the main references used by complainants to assess the legitimacy of their grievances, one should nonetheless underline that they tend to use principles recognized as being valid by both parties. In other words, the specific grammar or relational movement stressed in the letters leads complainants no to linger on viewpoints that belong to only one of the parties at stake and that eventually are alien or hostile to the other party. On the contrary, petitioners rather take into account the shared norms in which the relationship is embedded. Moreover, given the political context, they often assign priority to the other party's claimed principles. As a consequence, it seems hardly surprising that they should not only refer to moral rules whose legitimacy is taken for 
granted but also to the political claims made by the authorities as they are expressed in public pledges, laws and national directives.

However it would be wrong to interpret this widespread recourse to principles of official legitimacy as a willingness to conform to the rules. The links made by complainants between the particular situation faced and the general principles used to assign a meaning to it are indeed multiple, complex, uncertain.

First of all, political references that can be used to assess the factual and normative sense of a situation are many. As a matter of fact, the decisions and commitments of the political leadership, far from being consistent, have settled in a diversity of forms and expressions since 1949. These can be selected and combined by complainants in a variety of ways. As a consequence, shared official references assumed to be relevant and valid in order to make sense of concrete situations are not exclusive or mechanically determined but plural. They can be used and articulated by complainants in very different manners.

Second, complainants often resort to as many rules or principles as possible in order to demonstrate that the injustice experienced goes against a plurality of norms, as shown in the various extracts quoted in this text, thus ruling out the idea of merely obeying an exclusive rule or complying with it. Although some letters are embedded in a single normative dimension-legal, political or moral-, most accounts use a variety of common references, the meaning of each of them being thus altered by their mutual coexistence and interweavings. In other words, none of such references, including the political and official ones, enjoys any kind of supreme authority. Put together, they create a specific normative framework depending on the way they are organised into a hierarchy and combined.

Of course, political principles remain the common references which, given their political legitimacy, are the least likely to be questioned or contested by authorities. Hence, those addressing the Letters and Visits Administration partly rely on these least doubtful principles and norms. However, in doing so, complainants actually try to compel, or to put it more bluntly, to push those 
who made these official commitments to act in the desired way. Or, if not, acknowledge that their words and actions deeply differ.

Third, the mere quote of laws or official directives is not enough to give meaning to the facts exposed in the letters or during the visits. We can borrow here from Ludwig Wittgenstein, who considers that a word only makes sense as part of a language-game, which is itself part of a common form of life. He also indicates that in the explanation of meaning, judgements, sentences or propositions take priority over concepts or words (Glock, 2003). More simply put, the analysis should focus on the whole unit made up by the specific case at stake and the general forms, norms or principles used to assign a meaning to it, rather than just the latter. One possible explanation of a specific case, as well as the rule referred to, is indeed to be found in the connection made between the two - a connection revealing the knowledge and imagination of complainants. As a consequence, mentioning an official rule does not determine in an exclusive and unequivocal way the meaning assigned to the situation at stake.

If Kevin O’Brien's "rightful resistance” seems very appropriate to describe the recourse to official rules as a basis for justifiable expectations, it must indeed be emphasized that using these rules adequately does not suggest using it in an expected, predefined, ready-to-use fashion (O’Brien, I996, 2006). A correct use of an official rule or public pledge, as far as the grammar of action, is concerned can also be a new, unexpected or even transgressive use as is the case with the letter quoted above.

More pointedly, most letters in the corpus stem from the specific and try to identify, in a social context where the degree of semantic as well as normative indeterminacy is high, the general forms that may be helpful to interpret it. They are testing a diversity of links between the particular and the general, trying to measure their degree of legitimacy. We are here in a much different situation than during the "Speak bitterness meetings", where reporting specific cases and situations using the new ideological vocabulary was a way to show rather than demonstrate the new rules and norms that were to prevail. The examples provided appeared then self-evident; they seemed to be a direct expression of reality and tried to induce support to the new ideology while actually removing discus- 
sions about moral and political norms from public debate. The link between a particular example and a general principle was both invisible and presented as obvious. Moreover, in this specific case, the visible narrators-peasants speaking about bitter past experiences - were not those at the origin of the links established; they were taught to speak in a certain way and were not full authors of their words while the audience had no room for judgment.

On the contrary, today's petitioners, whatever their objectives and strategies, are brought to distinguish between fair and unfair, good and evil, legitimate and illegitimate. They are thus bound to use that specifically political ability that consists in making sense of a particular experience by referring it to generally shared forms, that is to a common world whose existence is thus assumed, tested and consolidated. Their judgements allow them to "place what they judge into the field of what makes sense to man"-as Ronald Beiner (I99I [1982], p.I38) beautifully puts it - and somehow acknowledge the multiplicity of the human condition highlighted by Hannah Arendt (1978, p.200).

\section{CONCLUSION}

The Letters and Visits Administration is often criticized in the literature as being inefficient; the requests or suggestions that its existence legitimizes are often dismissed as only reflecting specific interests. Besides, the great variety of situations, claims, actors and formats in which letters and visits are made, tends to exclude all attempts at generalization. However, the corpus of seven hundred letters gathered here, as fragmented and limited as it may be, invites us to underline the political dimension of this space of direct address to the authorities.

When examining the issue of protest in China, the stands of leading figures or the unfolding of collective action in its many forms are often looked into by scholars. The increase in large-scale incidents reported every year is used to stress the social tensions arising in today's China. These tensions are addressed in the literature available on social movements, which provides explanations in terms of political opportunity structures, activist networks or framing processes? 
This article deals with a less visible space for initiative and speech, which is occasionally publicized in the context of collective action or when grievances and claims are expressed on the Internet. Its lack of visibility, but also the specific forms of argumentation and contention observed, probably accounts for it being disregarded. As a matter of fact, although many feelings of injustice are not voiced there and although the spectrum of written and verbal statements is extremely varied, this is a space where specific situations are contested by complainants who at the same time outline the type of relationships that should prevail between human beings as well as the way they perceive themselves. It is thus an important space of initiative and judgment where complainants, although they are often unable to change the situations faced, can express that they are persons who reject such situations and are capable of reassessing the scope of actions and political norms to be expected because presumably shared. By "leaving the scope of undefended matters open" (Ricoeur, 1990, p.255), they pave the way for a sort of moral and political invention which, in spite of the use of negative rhetoric, is not limited to protection against infringements from the State and society but also aims at defending individuals' ability to act within society.

If the actions of most complainants are not explicitly political, the analysis of the corpus gathered for this study thus demonstrates a process of political subjectification extending much beyond the groups involved in officially recognized collective or political actions. This process is not based on a mere request for official principles and rules to be applied but on the negative judgements made of specific actions and situations in the light of the plurality of moral and political principles that they infringe. Rather than dismissing what separates them from the State and Party representatives they petition, complainants put forward the links that mutually bind them in spite of their dissimilar positions. Rather than challenging official measures and directives, they strive to reduce current normative uncertainties by selecting and reinterpreting laws and official pledges as promises whose meaning they contribute to establish. 


\section{BIBLIOGRAPHY}

ARENDT Hannah, 1958, The Human Condition, Chicago, Chicago University Press.

-, 1978, The Life of the Mind, London, Secker and Warburg.

-, 2005 (2003), Responsabilité et jugement, Jérôme Kohn (ed.), Jean-Luc Fidel (trad.), Paris, Payot.

BEINER Ronald, 199| (1982), "Hannah Arendt et la faculté de juger", in Hannah Arendt, Juger. Sur la philosophie politique de Kant, Paris, Seuil.

CHENG Anne, 1997, Histoire de la pensée chinoise, Paris, Seuil.

DESCOMBES Vincent, 20I0, "La question de l'individualité humaine", Philosophie, 106-2, p.38-56.

DIAO Jieceng, 1996, Renmin xinfang shilüe, [A Brief History of People's Letters and Visits], Beijing, Beijing jingji xueyuan chubanshe.

GAO Wangling, LIU Yang, 2007, "On a Slippery Roof. Chinese Farmers and the Complex Agenda of Land Reform", Études rurales, 179, p.19-34.

GAO Zhisheng, 2006, Zhongguo minqi weiquan di yi an [The first case of mobilization of Chinese private entrepreneurs to protect their rights], Taipei, Broad Press International.

GLOCK Hans-Johann, 2003, Dictionnaire Wittgenstein, Hélène Roudier de Lara et Philippe de Lara (trad.), Paris, Gallimard.

GUO Zhidu, 1992, Xinfang tansuo, (Exploring the Letters and Visits System), Taiyuan, Shanxi renmin chubanshe.

HINTON William 1966, Fanshen: A Documentary of Revolution in a Chinese Village, Monthly Review Press.

HUANG Philip, 1995, "Rural Class Struggle in China's revolution: From Land Reform to the Cultural Revolution, the Representational Reality and Objective Reality", Modern China, 21-I, p. 105-143.

MINZNER Carl, 2006, "Xinfang, An Alternative to the Formal Chinese Legal System", Stanford Journal of International Law, 42-I, p. I03-179.

O’BRIEN Kevin J., 1996, "Rightful Resistance", World Politics, 49-I, p.31-55. 
-, LI Lianjiang, 2006, Rightful Resistance in Rural China, Cambridge, Cambridge University Press.

PERRY Elizabeth J., SELDEN Mark (eds.), 2000, Chinese Society: Change, Conflict and Resistance, London and New York, Routledge Curzon.

Qianfeng (Vanguard), 2006, [monthly journal], II.

Renmin xinfang, 2006, [monthly journal], 3.

REVAULT D'ALLONES Myriam, 1991, "Qu'est-ce que juger? Hannah Arendt lectrice de Kant", in Futur Antérieur, août, [s.p.]: <http://www.multitudes.net/ Qu-est-ce-que-juger-Hannah-Arendt/>.

RICOEUR Paul, 1990, Soi-même comme un autre, Paris, Seuil.

Suku Fuchou. Suku dianxin cailiao [Speaking bitterness and seeking revenge. Material regarding exemplary speak bitterness accounts], 1948, [s.I.], Jinchayi junqu zhengzhi bu (Political department of the military region of JinChaYi).

THIREAU Isabelle, HUA Linshan, 2010, Les Ruses de la démocratie. Protester en Chine, Paris, Seuil.

-, 2012, "Les déboires du pasteur Lin: une dénonciation venue des masses à Shanghai au début des années 1950", Le Mouvement social, 239, p.61-90.

YU Jianrong, 2005, "Xinfang zhidu diaocha yu gaige silu" [Investigation on the Letters and Visits Institution and some thoughts about its reform], in Blue Book of China's Society 2005. Analysis and Forecast on China's Social Development, Huang Ping and Lu Jianhua (ed.), Beijing, Shehui kexue wenxuan chubanshe, p.25-43.

Xinfang, jubao, shensu bibei [Necessary documents for letters and visits, reports and appeals], 1990, administrative handbook, Beijing, Zhongguo zhengfa daxue chubanshe.

Zhengming, 2004, [monthly journal], 6. 
